\title{
Integrating Local Culture into Forest Conservation: A Case Study of The Manggarai Tribe in Ruteng Mountains, Indonesia
}

\author{
Elisa Iswandono ${ }^{1 *}$, Ervizal Amir Muhammad Zuhud $^{2}$, Agus Hikmat $^{2}$, Nandi Kosmaryandi ${ }^{2}$
}

\begin{abstract}
${ }^{1}$ Graduated School of Bogor Agricultural University, Dramaga Main Road, Campus IPB Dramaga, Bogor, Indonesia 16680
${ }^{2}$ Department of Conservation of Forest Resources and Ecosystem, Faculty of Forestry, Bogor Agricultural University, Academic Ring Road, Campus IPB Dramaga, PO Box 168, Bogor, Indonesia 16680
\end{abstract}

Received May 16, 2015/Accepted July 6, 2015

\begin{abstract}
Ruteng Mountains in Indonesia are inhabited by people from the tribe Manggarai. Local culture of Manggarai community has a role to conservation and it needs to be integrated in the conservation of natural resources. Where conservation is defined as the management of the sustainable use of natural resources, the integration of local culture into conservation will open up a space of the emergence of the creativity and innovation in solving problems offorest conservation. This study aims to explore and describe to what extent the culture of Manggarai contributes to conservation activities in the protected areas and the possibility of the culture to be integrated within conservation policy. The study employs a qualitative research through ethnographic approach. The qualitative data in 2014 was obtained through field observation, interviews, data from relevant agencies, and related literature. The study shows that the Manggarai community has practiced conservation values, norms, and tradition since hereditary. Manggarai culture related to conservation could be integrated into the activities of the protection, preservation, and sustainable use of natural resources.
\end{abstract}

Keywords: integration, management, protected, sustainable use, natural resources

*Correspondence author, email: eiswandono@gmail.com,phone: +62-81334707201

\section{Introduction}

Forest as a whole is cultural environment that becomes the foundation living system that sustains the life of forest communities. The culture is formed of continuous reciprocal relationship with the environment of forest resources (Nugraha \& Murtijo 2005). Cultures around the forest is unique and specific as adapt to the changes for hundreds of years so as to suit the characteristics of the forest. The implementation of conservation programs needs to duly consider the local ethnic culture that will suit the characteristics of the forest.

The term 'conservation' consists of the word 'con' (together) and 'servare' (keep/save) who have an understanding of the efforts to maintain or keep in wise use. This idea was proposed by Theodore Roosevelt (1902) who was the first American who argued about the concept of conservation. The understanding of conservation is now translated as the wise use of nature resource or the management for the sustainable use. Conservation of forest management programs should integrate local systems that adapt to the changes for hundreds of years. Conservation theory is universal, but its application was duly unique to each location.
Traditional communities in and around protected areas have a role to support management with local knowledge in sustainable forest use (Junior \& Sato 2005). Local knowledge is not just to be documented but to be understood and integrated, and the problem of power imbalance between the indigenous knowledge system and the scientific knowledge system has to be addressed by integrating it with the scientific knowledge system (Ruheza \& Kilugwe 2012). Cultural integration into conservation is expected to improve understanding of conservation that could affect conservation policy (Young et al.2014).

Culture in forest conservation, or better known by local knowledge based conservation differs from science based conservation. Science based conservation uses logic and science approach, while indigenous communities using local knowledge. Local knowledge based conservation have a common goal of forest sustainability for the welfare of the community, but local knowledge is poorly understood because it was considered old-fashioned and illogical (Kosmaryandi 2012a). Local wisdom in utilization of natural resources since hereditary have a role in forest conservation through sustainable use traditionally affecting forest sustainability (Pei et al. 2009; Pei 2013). Local knowledge based conservation is tested with time so that the 
same as process of trial and error, while conservation is based on testing scientifically so that both have a scientific truth. A thorough understanding of local knowledge through ethnographic studies will reveal the cultural side in conservation.

The idea of the establishment of an area of protected forest in Indonesia is always with consideration of scientific values in the forest area. Recognition of the importance of protected areas nationally and internationally, the conservation goal achievement is normally based on the scientific value of the ecological side without considering the existence of local communities. A scientific values of natural ecosystems should not be contrasted with the viewpoint of different local communities. For local communities, the important values of a conservation area has not been able to address the needs of life, are often sacrificed tenure and access to natural resources for the sake of a virtual values that are not understood. The real benefit should touch the fulfillment of everyday life. National and global interest in conservation should not ignore the fact that there is an existing local communities in and around protected areas. Efforts to maintain the idea of conservation areas through legal mechanisms and without prejudice to the rights of local peoples could be an alternative choice in the effective management of protected areas.

Researches that integrates local culture have been carried out by a different research focus, some of which are: focus on zonation (Kosmaryandi 2012a; Kosmaryandi 2012b; Freitas \&Tagliani 2009), difference, methods and process integration (Bohensky \& Maru 2011), vegetation classifications (Naidoo \& Hill 2006), traditional ecological knowledge of species population (Fraser et al. 2006;
Gagnon \& Berteaux 2009; Moller et al. 2004). While the purpose of this study was to analyze local knowledge resource conservation of biodiversity in Manggarai culture with ethnographic studies and integrate it with conservation

\section{Methods}

This research was carried out for 6 months from July to December 2014. There are 70 villages around Ruteng Forest and 22 villages around Todo Forest. The sample location includes 3 kampongs (small traditional village), 2 kampongs located around Forest Ruteng and one other kampong in the Forest Todo (Figure 1). The 3 kampongs samples were chosen purposively consider the distance from the city district Ruteng, namely: Kampong Mano is $10 \mathrm{~km}$ from the town of Ruteng, Kampong Lerang $20 \mathrm{~km}$, and Kampong Wae Rebo is about $60 \mathrm{~km}$. Kampong Wae Rebo is an isolated area in the enclave Forest Todo as a benchmark that indicated a good forest condition managed by local people. Another consideration of the selection of samples is the sameness of their ethnicity, language, and culture of the villagers of the 3 villages.

The research data in the form of ethnographic data that revealed 9 factors, namely the location of the natural environment and demographics, the origin and history of the tribe, language, technology systems, livelihood systems, social organization, systems of knowledge, art and technology systems (Kontjaraningrat 2002). Acquisition of data through participant observation, focus group discusion (FGD), in-dept interviews, and literature. Interviews using open-ended interviews with informants set based on the status and role in the community by purposive and snowball (Sugiyono 2010).

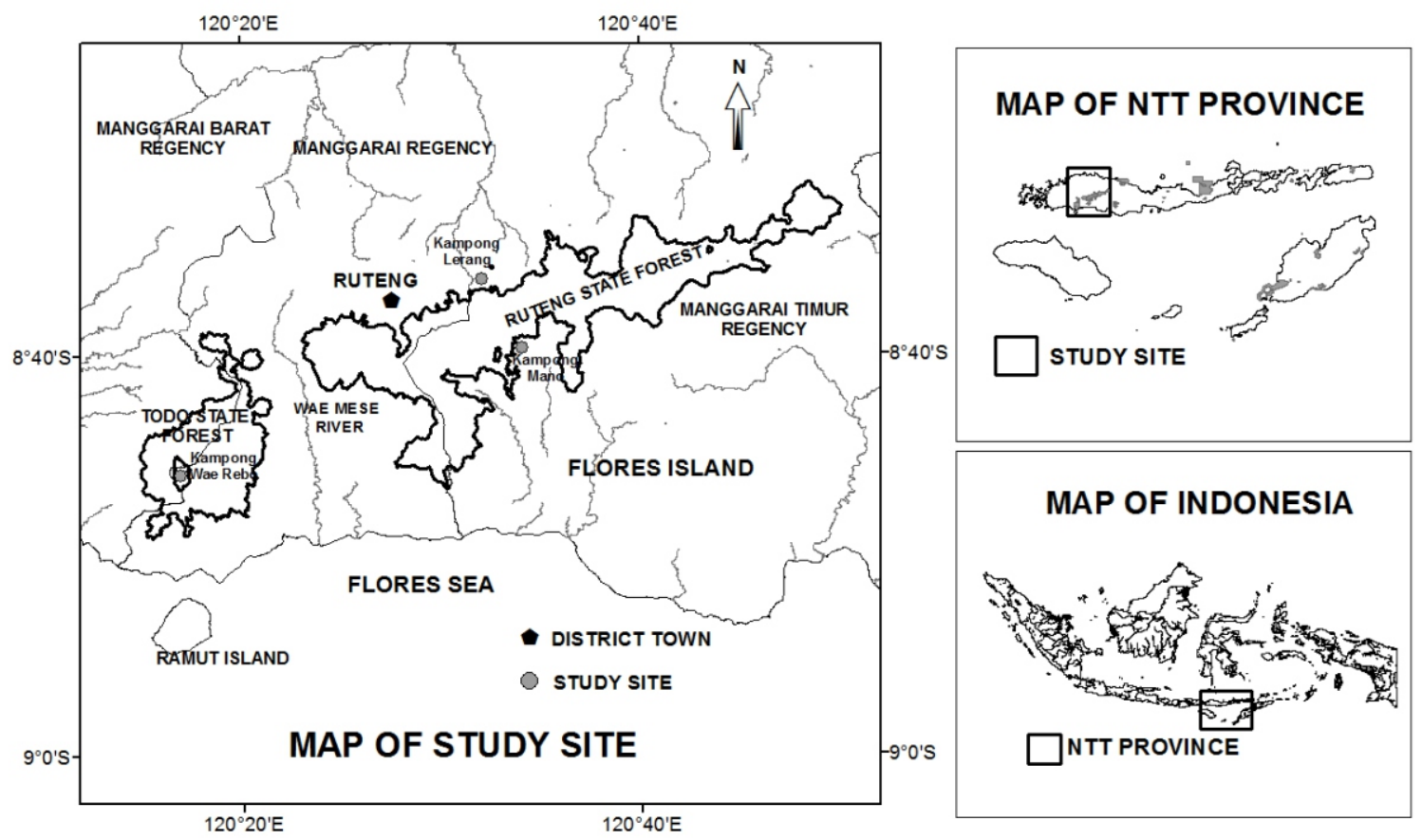

Source: Administration Maps of Nusa Tenggara Timur Province in 2010 and Regulation of the Minister of Forestry Number: SK.3911/Menhut-VII/KUH/2014, 14th Mei 2014, rule that concerning Forest Area and Marine Conservation in East Nusa Tenggara Province.

Figure 1 Map of study sites. 
Determination purposively informants who have an understanding of biodiversity resources based on the initial guidelines one informant who recommend other informants (i.e. snowball approach). FGD goal is to get the data of forest species use, traditional tools, and culture related to conservation while in-depth interviews to obtain data ethnographic. There were 9 villagers in Kampong Mano, 15 in Lerang, and 10 in Wae Rebo were in involved FGD and conducted by the researcher with assistance from locals. Open-ended interview were conducted with 3 kampong's leader (tua golo) and 3 others people who get forest products.

Informants in 3 kampong's are 5 persons, consisting of kampong's leader (tua golo), traditional leader's who divide communal land (tua teno), and people who get forest products. Interviews were conducted in an open area in the yard, garden, forest, and on the edge lake to make respondents feel free. Manggarai village community can speak Indonesian well but prefers to speak in Manggarai language when talking about the culture. Luckily, the researcher can understand their language. In addition to village communities, open ended interviews were conducted also with the 2 leaders of local NGOs, namely Yayasan Pembangunan Tani and Sanggar Lawe Lenggong which is working in conservation and culture, and also 2 people Manggarai District local officials who understand the culture of conservation with assistance locals. Measurement validity of the data through the public's understanding on local wisdom by triangulation, ie comparing the results of the informant interviews and participant observation. Conservation actions are integrated into conservation activities (Figure 2).

\section{Results and Discussion}

Development and its impact to community and conservation Ruteng Mountains are located in the western of Flores Island, Nusa Tenggara Timur Province, Indonesia. Ruteng Mountains are composed of Ruteng Forest and Todo Forest separated by Wae Mese River is mountain forests which is the most moist montane forests widest in Nusa Tenggara and serves as a sanctuary for wildlife, especially birds. Todo Mountain has a peak altitude of about $2000 \mathrm{~m}$ (Trainor \& Lesmana 2000). Ruteng Forest is a mountain chain of seven peaks, namely Golo Ranamese $(1,790 \mathrm{~m})$, Poco Nembu (2,030m), Poco Mandosawu (2,350m), Poco Ranaka (2,140m), Golo Leda (1,990m), Ponte Nao (1,920m), and Golo Curu Numbeng (1,800m) (Simbolon 1998).

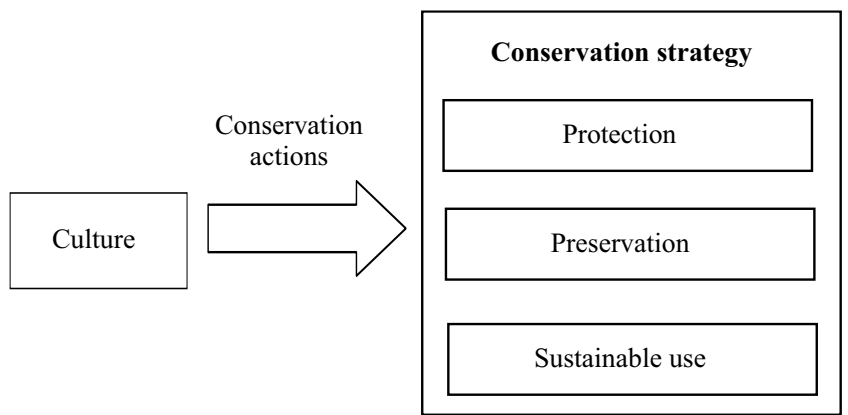

Figure 2 Analysis of the integration of local knowledge and conservation.
The Dutch began to colonize the West Flores in the early 19th century after the conquest of the Bima Kingdom and Bugis Kingdom. Currently, inhabited in the coastal areas are Bima and Bugis society while the mountainous region is settled by the Manggarai community. Manggarai includes 6 languages, they are Komodo language on Komodo Island, Waerana language in East Manggarai, Rembong language ranging from Rembong to North Ngada, language Kempo language in the West Manggarai, and Rajong language in Rajong, Manggarai Kuku in the District Manggarai and East Manggarai who have somewhat different dialects (Verheijen 1991). Manggarai people who live in the mountains of Ruteng speaks in Manggarai Kuku language.

Manggarai people is the descendents of mixed marriage between the original Manggarai with migrants from outside Flores that affect their belief in the existence of a supreme manifestation called Mori Keraeng (Verheijen 1991). Region village located at altitude of 900-1,300 m asl makes people dependent on crops and forest resource extraction. The village is located far from the town which has a fairly dense settlement. Lush mountains provide various necessities of life from forest and agricultural products so as to establish a culture of conservation.

Manggarai people is as one of the Murba tribes who live in modern times but still have a visible state of primeval nature of their religious system (Hadiwiyono 1985). Manggarai community often mentions the name Mori Kraeng instead of the name of God. Mori Kraeng is not the native language but from Bugis language. Mori means God and Kraeng means 'king' and it is the term for the supreme authority in the spirit world (Verheijen 1991). Manggarai people believe the natural and supernatural is a distinct entity dimension. Supernatural beings have a major effect on human life and should be in harmony with nature. Faerie who haunted usually located in a large tree, sacred forests, ravines and caves so that traditional ceremonies goal is to get permission when doing activities in a haunted place.

This belief affects people's lives are subject to the unseen world that perform traditional ceremonies. The main traditional ceremony is penti, a ceremony closing the year to harvest a garden which is actually a unity of three ceremonial worship of the three territorial spirits. They are the garden keeper spirit called teno through barong lodok ceremony, darat as a spirit who dwells in nature as in the spring through barong wae ceremony, and naga golo that dwells in the middle of the village.

The traditional ceremony is a form of communication and worship the unseen forces that have a higher position that determines life. According Verheijen (1991), Manggarai community prayed to Mori Kraeng if they want to cut down a large tree or open garden space for God to remove evil spirits. According to the story of Manggarai elders, missionaries introduced the concept God who became a bridge between the living and dead world. This concept is accepted by most people because it fits Manggarai ceremonies called kelas, a traditional ceremony to deliver the spirits of the dead from the human world to the spirit world.

Manggarai people have agricultural calendar that marked the new year celebration with penti ceremony that marks the beginning of rainy season activities. This calendar is the 
computation time of planting heritage associated with rainy and dry seasons. The traditional education system has been altered by the presence of formal education, people send their kids minimal elementary school. Accessibility and electricity are quite good though limited to an area on the edge of the highway. Communication from the area outside of the village is possible with the presence of a cell phone signal even though sometimes there is only have a weak signal and even no signal in remote areas such as in the Kampong Wae Rebo. Rice fields are very limited and is on a slope that is hard to apply with modern farming technology, but have a good irrigation system for twice harvesting. Farm management is still traditional using organic systems but some people have started to use fertilizers and chemical pesticides.

Leader in a kampong originally was tua golo but this time there is a village head who administers a few kampong. Tua golo is not under authority of village head so the village head represent formal leader to handle administration while tua golo is informally to handle social problems. This time the Catholic priest is also the spiritual leader besides tua golo. The same thing happened in other areas, such as: coastal villages of Kanyakumari, South India (Sundar 2012), that local people have Catholic faith and identity are deeply rooted and thoroughly indigenised; Catholic priest introduce new ideas and directives from the World Church (for instance, around theological purity and liturgical practice), and the need to inculturate and remain indigenous, especially in the context of Hindu nationalism. Although there have been changes, tua golo still play an important role in the lives of rural communities, especially those living around the forest because social ties of kinship, communal land ownership and traditional ceremonies led by tua golo.

Communal agricultural land is getting narrower with increasing off springs so that people explore the village past (bangka) which is currently in a state forest. The same thing was expressed by Sinu et al. (1999), that Manggarai community will continues to recognize bangka as communal land despite hundreds of years leaving the region. Generally, the Manggarai community does not practice agricultural rotation system because the limited communal land except in kampong Wae Rebo where there is enough communal land. The Catholic Church requires customary marriage followed by the church blessing, forbids to live with customary marriage partner. The Church builds hospitals, roads, water supply, training crafts, farming and other training. The rural areas around the forest becomes more modern, especially with the construction of schools, roads and drinking water facilities.

The integration of local culture and its problem Traditional ecological knowledge (TEK) can complement the information and identify the direction of the management but with limitations. The integration of TEK into the management is an efficient method in time and costs in conservation management and also a solution of social problems (Rist et al. 2010). Forest management should consider aspect of the ecological, social and cultural. The use of the social, and cultural aspects can improve the effectiveness of management, to accommodate the aspirations and participation of local communities in forest management (Uprety et al. 2013).

Management of conservation area requires collaboration of various stakeholders and integration of local knowledge in sustainable forest management (Tongkul et al. 2013). Conservation strategies carried out through three activities, there are (1) the protection, to protect the life support system; (2) the preservation, to preserve of plants, animals and their ecosystems, and (3) sustainable use of environmental conditions of conservation areas and wildlife. Manggarai culture that can be integrated into protection are sacred forest around the spring, idioms and the role of traditional institutions on conservation; preservation are sacred species and culturally important species and ecology; sustainable use are subsistence utilization of non timber resources.

Sacred forest around the spring Important traditional ceremonies related to conservation is barong wae to worship the spirits who guard the spring water that become the reason to maintained forest. At the study site, barong wae belief led to preserve forests Mano called pong Dode (4.3 ha) and forest around Lake Ranamese (11 ha) to meet irrigation needs. Sacred forests in state forests as a religious ritual and reverence to the ancestors should be accommodated as a core zone that gives advantages in ecology (Kosmaryandi 2012b). Scientific values a conservation area can only be understood if the forest communities provide real benefits such as clean water from springs to meet the needs of water every day.

Plants and wildlife in the sacred forests are well protected because of the prohibition to hunt wildlife and take the plant forest. Ranamese Lake as a sacred area for villager's lerang is a habitat for 45 birds. Two water birds living in the lake are gray teal (Anas gibberifrons (Miller 1842)) and little grebe (Tachybaptus ruficollis (Pallas 1764)). Some of protected birds living in the forest around the lake are grey goshawk (Accipiter novaehollandiae (Gmelin, 1788)), brahminy kite (Haliastur indus (Boddaert 1783)), changable hawk eagle (Spizaetus cirrhatus, (Gmelin 1788)), black winged kite (Elanus caeruleus, (Desfontaines 1789)), olive back sunbird (Nectarina jugularis (Linnaeus 1766)), and helmeted friarbird (Philemon buceroides (Swainson 1838)) (Widodo 1998). While sacred forests around Wae Rebo is a habitat for endemic wildlife such as the pygmy owl (Otus alfredi (Hartert 1896)), flores crow (Corvus florensis (Buttikofer, 1894)), flores giant rat (Papagomys armandvilley (Jentink, 1892)), and reticulated python (Python reticulatus (Schneider 1801)) (Trainor \& Lesmana 2000).

Idioms Idioms in local beliefs can manifest in conservation action. Idioms are part of the belief system of the people who influence the mindset and behavior that later manifested itself in conservation action. Idioms is intellectual of local people, rootedness in the traditional and spiritual (Chennells 2013). Traditional life gives wisdom to the people of Manggarai to have wise words of conservation for example mbau eta temek wa, tela galang pe'ang kete api one which means "when at the top of the mountain under the green then be a lot of water, in the furnace have enough firewood, on top of enough food to be cooked" and are actually the same as the term conservation is sustainable use.

Elder stated that "puar hitu anak rona", which means 
forest is "anak rona". Anak rona is a descendant of the woman who should be appreciated. This concept comes from traditional belief that the earth is the mother and the sky that produce rain is the father. The forest is seen as the daughter of the sky and the earth so is seen as anak rona. This belief produce roko molas poco ceremony, a traditional ceremony to apply large worok tree (Dysoxylum nutans (Blume) Miq) such as applying for a girl for the main pillar of traditional house.

The role of traditional institution on conservation Golo leadership plays a more important role in forest conservation than the head of the village. This is in accordance with the opinion Sinabutar (2014) that state forests in Indonesia prefer the legality than legitimacy, so that informal institutions are often gain more recognition in forest management.

Traditional community contributes to the forest conservation if they receive benefiting from the forest either directly or indirectly. In the Kampong Wae Rebo, local communities were given permission to take the wood to build a traditional house from Todo Forest and manage tourism as Todo Forest has better forest cover than Ruteng Forest (Figure $3 \&$ Figure 4 ). There are more foreign tourists coming to Todo Forest than to Ruteng Forest (Table 3). More domestic tourists come to Forest Ruteng because natural

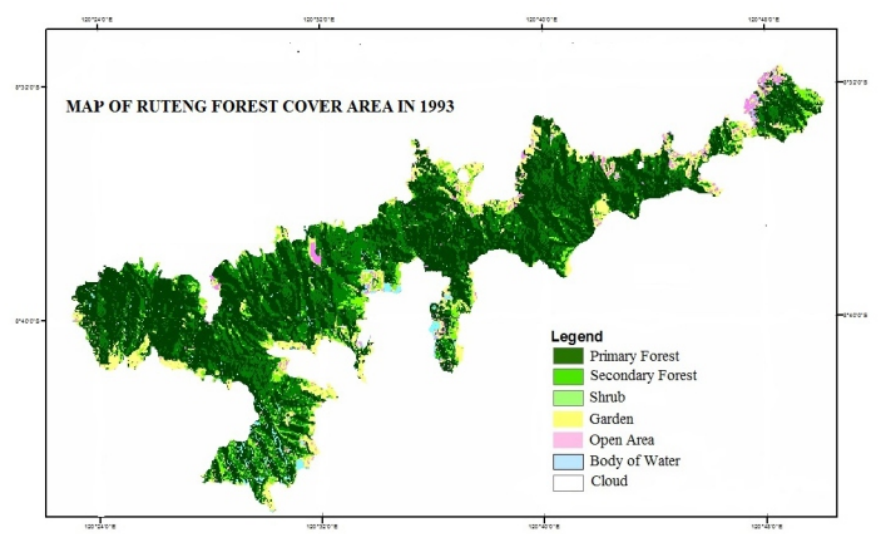

view is the main attraction for tourism while in Forest Todo is cultural tourism beside natural view may attracted more foreign tourist and less of domestic tourist. Cultural tourism that attract many foreign tourist is the home of traditional customs and traditional daily life in forest enclave such as organic farming, daily activities with traditional tools, vegetables from forest and so on.

Indigenous people solve the problem with culturally process such as customary fine. The customary law gives deterrent effect on social sanctions in kampong Wae Rebo such as shame and excluded from society. Social punishment has the effect of preventing unlawful behavior so that each activity in the kampong goes well.

Local community of Ruteng Forest earn cash income by selling forest product while resident in kampong Wae Rebo receives more income from tourism (Table 4). The utilization of Ruteng Forest plants for building and firewood commercially lead the forest to degradation. This is in accordance with the opinion of Pei et al. (2009) that the utilization of forest products for commercial will lead to forest degradation. Todo Forest cover area is better than Ruteng forest from 1993 to 2014 (Table 1). The decrease was a result of the expansion of shrubs, gardens and open areas for dry agricultural land and settlements (Table 2).

Sacred species Traditional community believes in totem for

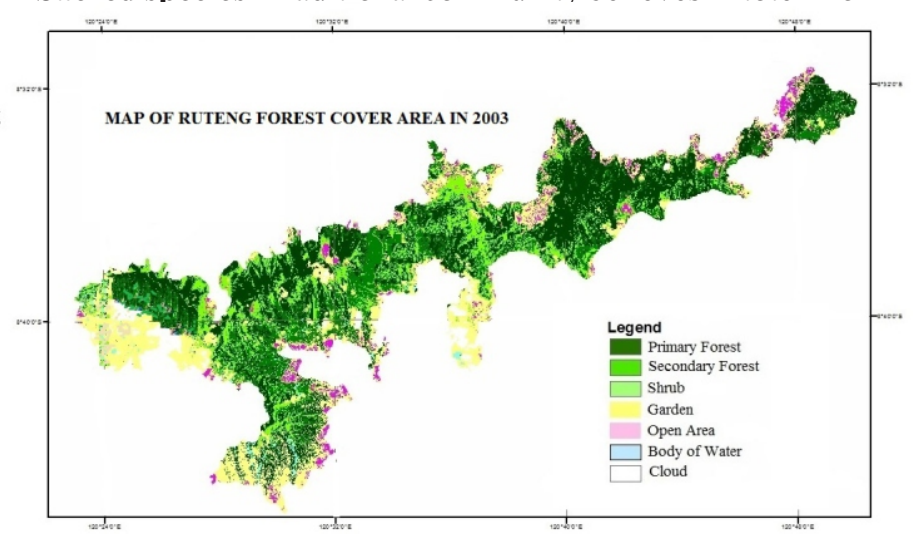

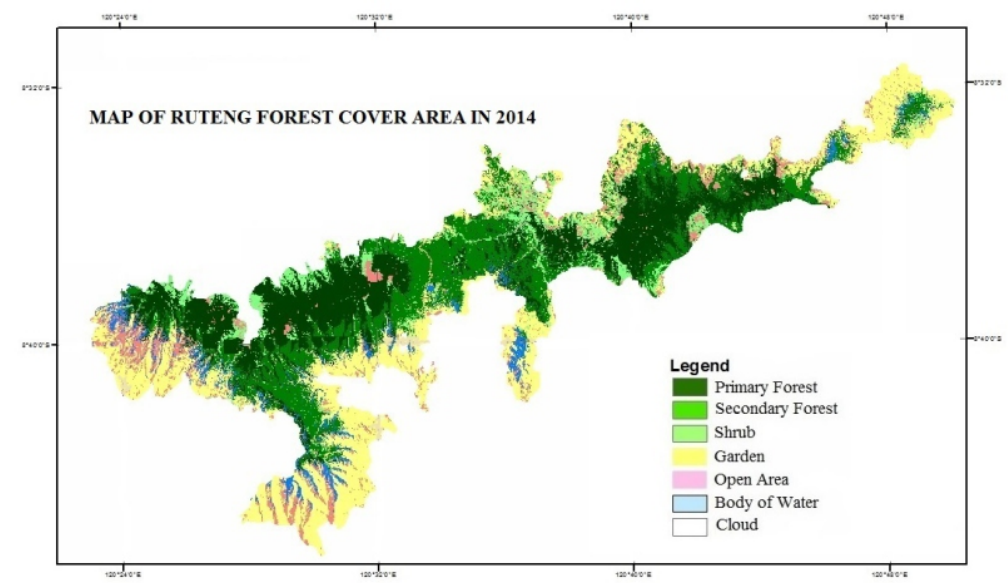

Source: (1) Landsat TM Image LT5113066199332 for forest cover area in 1993, (2) Landsat TM Image LT5113066200330 for forest cover area in 2003 (3) Landsat TM Image LC8113066201425 for forest cover area in 2014 Remark: Data were analyzed with ERMapper 7.1 and ground check

Figure 3 Ruteng Forest cover on the analysis of Landsat imagery in 1993, 2003, and 2014. 

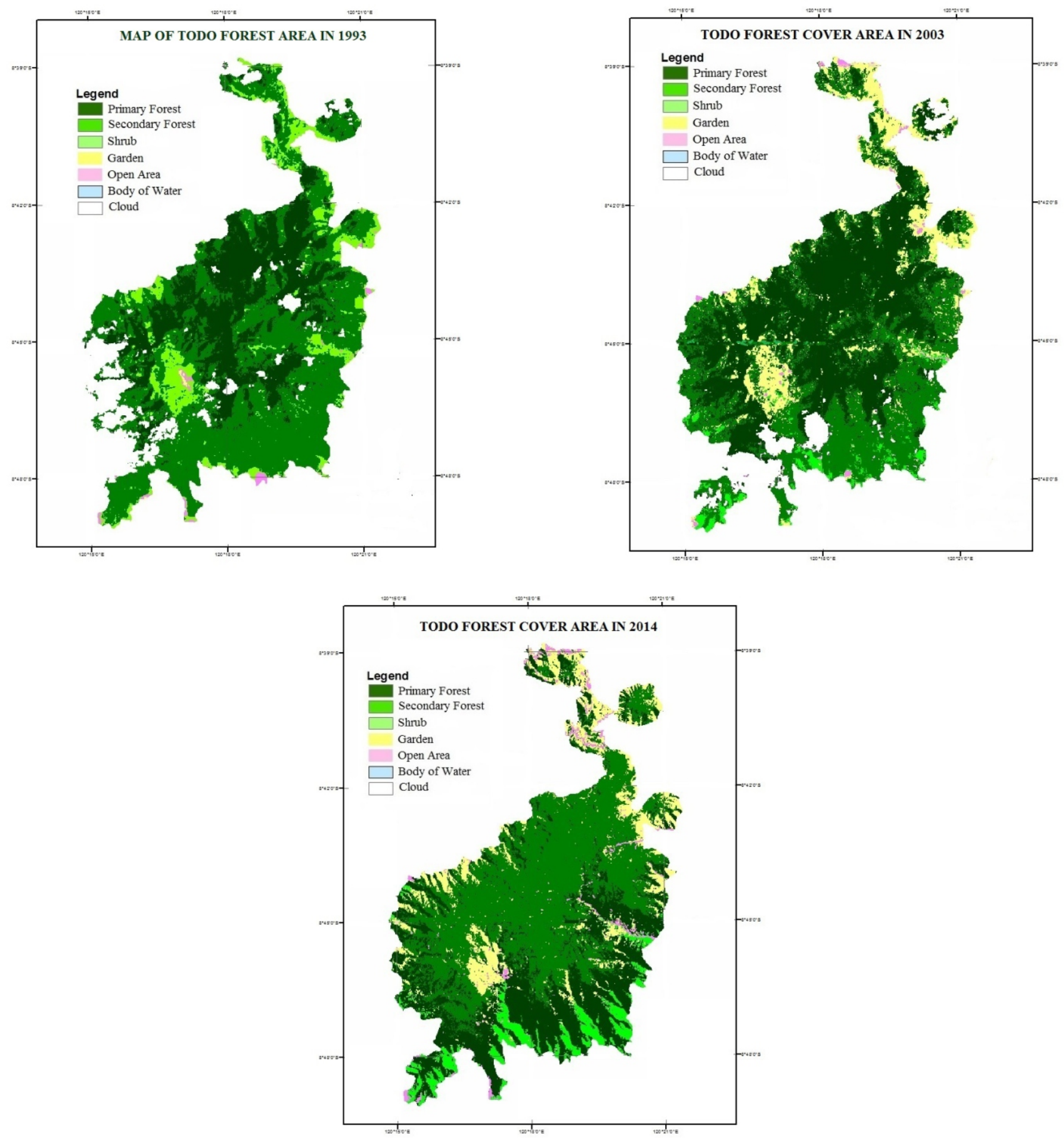

Source: (1) Landsat TM Image LT5113066199332 for forest cover area in 1993, (2) Landsat TM Image LT5113066200330 for forest cover area in 2003 (3) Landsat TM Image LC8113066201425 for forest cover area in 2014. Remark: Data were analyzed with ERMapper 7.1 and ground check

Figure 4 Todo Forest cover on the analysis of Landsat imagery in 1993, 2003, and 2014.

wildlife protection linked to the past mythical story that bans the hunting of certain wildlife. Totem is still believed to be due to violations of the totem belief has impact on health for example itching all over the body and would only heal by running around the village carrying chicken cages above the head. Totem helps conserve protected and endemic species such as the pygmy owl (Otus alfredi (Hartert 1896)), flores giant rat (Papagomys armandvilley (Jentink 1892)), flores crow (Corvus florensis (Buttikofer 1894)), hedgehog (Hystrix brachyura (Linnaeus 1758)), and others.

The tradition of sacred species could provide a powerful tool for ensuring biodiversity conservation through community participation (Khan et al. 2008). Sacred species naturally maintain the species population in the wild, for 
Table 1 Todo Forest cover in 1993,2003 and 2014

\begin{tabular}{lcccccc}
\hline \multirow{2}{*}{ Class/Region } & \multicolumn{7}{c}{ Land cover area and the percentage } \\
\cline { 2 - 7 } & \multicolumn{2}{c}{1993} & \multicolumn{2}{c}{2003} & \multicolumn{2}{c}{2014} \\
\cline { 2 - 7 } & Area (ha) & $\%$ & Area (ha) & $\%$ & Area (ha) & $\%$ \\
\hline Primary forests & $3,841.92$ & 34.89 & $3,740.67$ & 33.97 & $3,739.43$ & 33.96 \\
Secondary forests & $4,951.12$ & 44.96 & $5,012.65$ & 45.53 & $4,983.82$ & 45.26 \\
Shrubs & $1,453.38$ & 13.20 & 300.69 & 2.73 & 678.96 & 6.17 \\
Garden & 484.92 & 4.40 & $1,296.00$ & 11.77 & $1,372.95$ & 12.65 \\
Open area & 32.48 & 0.30 & 115.02 & 1.05 & 235.62 & 2.14 \\
Body of water & 0 & 0 & 0 & 0 & 0 & 0 \\
Cloud & 246.96 & 2,243 & 545.75 & 4.96 & 0 & 0 \\
\hline Total area & $11,010.78$ & 100 & $11,010.78$ & 100 & $11,010.78$ & 100 \\
\hline
\end{tabular}

Source: Landsat imagery analysis results of todo forests in 1993, 2003 and 2014

Table 2 Ruteng Forest cover in 1993, 2003, and 2014

\begin{tabular}{lrrrrrr}
\hline \multirow{2}{*}{ Class/Region } & \multicolumn{7}{c}{ Land cover area and the percentage } \\
\cline { 2 - 7 } & \multicolumn{1}{c}{1993} & \multicolumn{2}{c}{2003} & 2014 \\
\cline { 2 - 7 } & Area (ha) & $\%$ & Area (ha) & $\%$ & Area (ha) & $\%$ \\
\hline Primary forests & $16,272.36$ & 52.41 & $10,768.32$ & 34.69 & $8,272.26$ & 26.65 \\
Secondary forests & $7,409.16$ & 23.87 & $4,915.72$ & 15.83 & $7,379.46$ & 23.77 \\
Shrubs & $2,134.08$ & 6.87 & $5,636.79$ & 18.16 & $2,808.09$ & 9.05 \\
Garden & $3,545.28$ & 11.42 & $7,387.92$ & 23.80 & $8,703.09$ & 28.03 \\
Open area & 826.56 & 2.66 & $1,305.00$ & 4.20 & $2,675.25$ & 8.62 \\
Body of water & 438.84 & 1.41 & 373.41 & 1.20 & $1,207.26$ & 3.89 \\
Cloud & 419.13 & 1.35 & 658.25 & 2.12 & 0 & 0 \\
\hline Total area & $31,045.41$ & 100 & $31,045.41$ & 100 & $31,045.41$ & 100 \\
\hline
\end{tabular}

Table 3 The number of tourists in Ruteng Forests and Todo

\begin{tabular}{ccccc}
\hline & \multicolumn{2}{c}{ Ruteng Forest } & \multicolumn{2}{c}{ Todo Forest } \\
\cline { 2 - 5 } Year & $\begin{array}{c}\text { Domestic } \\
\text { tourists }\end{array}$ & $\begin{array}{l}\text { Foreign } \\
\text { tourist }\end{array}$ & $\begin{array}{c}\text { Domestic } \\
\text { tourists }^{1}\end{array}$ & $\begin{array}{c}\text { Foreign } \\
\text { tourist }\end{array}$ \\
\hline 2010 & 5 & 4 & - & 334 \\
2011 & 1391 & 78 & - & 425 \\
2012 & 145 & 141 & - & 573 \\
2013 & 305 & 167 & - & 679 \\
2014 & 808 & 449 & - & 2493 \\
\hline${ }^{1}=$ & No data because of not many domestic tourists came Todo Forest so that \\
there was no record &
\end{tabular}

examples beringin tree as a sacred tree will continue to grow and die naturally. Long-tailed macaques (Macaca fascicularis (Raffles 1821)) in the Mano sacred forest still remain despite the surrounding area is a garden and residential community because the long-tailed macaque is the totem Mano community

Culturally important species Important species forming cultural identity and role in meeting the needs of life. Each species has a different function so that some species are more important than the others (Turner 1988; Cristancho \& Vining 2004, Garibaldi \& Turner 2004). Culturally important species Manggarai people are teno (Melochia umbellata (Gmel.) Kurz) tree for building materials, medicinal plants, firewood, rope material, fence, myths, legends and rituals. Every Manggarai house uses wood teno (Melochia umbellata (Gmel.) Kurz) as one of the pillar of the house. The name of teno is the same as the name of the God who guard the yard and also the name of traditional leader's divider communal land (Iswandono 2015). According Zuhud et al. (2007) that 
Table 4 Comparison conditions of traditional village in the Ruteng Forest and Todo

\begin{tabular}{|c|c|c|}
\hline Description & Ruteng Forest & Todo Forest \\
\hline Forest area (ha) & $32,245.6$ & $10,089.2$ \\
\hline Forest covering & A decrease in forest cover & More stable forest cover \\
\hline Name of kampong & Mano and Lerang & Wae Rebo \\
\hline Populations & $\begin{array}{l}\text { Mano }=1916 \text { people ( } 399 \text { family); } \\
\text { Lerang }=409 \text { people ( } 94 \text { family) }\end{array}$ & Wae Rebo $=320$ people ( 32 family) \\
\hline Average monthly income ${ }^{1}$ (IDR) & $389.703,00^{2}$ & $449.717,00^{3}$ \\
\hline Modern agricultural activities & $\begin{array}{l}\text { Some people have been using chemical } \\
\text { fertilizers and pesticides. } \\
\text { Clove gardens around the yard of the } \\
\text { house in Mano and coffee in Lerang is } \\
\text { well kept. }\end{array}$ & $\begin{array}{l}\text { Organic Agriculture } \\
\text { Coffee plantations are located far } \\
\text { enough away from home and not kept } \\
\text { properly. }\end{array}$ \\
\hline $\begin{array}{l}\text { Utilization of building timber in } \\
\text { the forest }\end{array}$ & No timber utilization permits. & $\begin{array}{l}\text { Permission to take special timber for } \\
\text { traditional house. }\end{array}$ \\
\hline Tourism management & Tourism managed by central government & Tourism managed by local people. \\
\hline $\begin{array}{l}\text { Management of traditional } \\
\text { village }\end{array}$ & It is difficult to build a traditional house. & Well managed traditional village. \\
\hline $\begin{array}{l}\text { The responsibility of forest } \\
\text { conservation }\end{array}$ & Forests considered a state responsibility. & $\begin{array}{l}\text { Sense of belonging and maintaining } \\
\text { forest. }\end{array}$ \\
\hline Cash income from forest & $\begin{array}{l}\text { Cash from selling timber, firewood, } \\
\text { vegetables, fruit, and fish. }\end{array}$ & $\begin{array}{l}\text { Cash from cultural tourism and } \\
\text { nature tourism forest. }\end{array}$ \\
\hline Tourism ticket price (IDR) & $10.000,00$ for government & $250.000,00$ for local people \\
\hline
\end{tabular}

${ }^{1}=$ data from http://ntt.bps.go.id/linkTableDinamis/view/id/44, ${ }^{2}=$ Data revenue per capita per year divided by 12 months of people in Manggarai Timur

Regency, ${ }^{3}=$ Data revenue per capita per year divided by 12 months of people in Manggarai Regency.

the community is aware of potential natural vegetation and the real benefits of a species underlying willingness to do conservation, even incorporate religious values for conservation.

Culturally important species and ecological (eco cultural species) is a fig tree (Ficus variegata) (Iswandono 2015). Culturally important and ecological species provide benefits in conservation actions undertaken by the community. Conservation action is based on a voluntary as benefiting both for cultural and ecological benefits. Sacred tree is a type of fig (Ficus benjamina) which were planted in the middle of the village and is believed to be the home God. Most of the ara tree (Ficus variegata) in a forest of more than $100 \mathrm{~cm}$ in diameter because it is not used as a building material and the presence of customary sanctions if the tree is cut down because the public myth that this tree can improve the flow of water in the spring. People uses this plant as vegetables, fruits, herbs and livestock feed. In the rituals to worship the wellspring guardian spirit called barong wae, people sometimes plant ara tree around the well spring.

Subsistence utilization of non timber When local people use a diversity of plants from diverse habitats, then the pressure on any particular type of wild plant in any particular habitat will be reduced. This will help to maintain forest systems generally in a good condition, being good for species diversity as a whole (Pei et al. 2009). Utilization of nontimber relatively sustainable is a form of interference at a medium level (intermediate) that impact sustainable maintain the level of biodiversity in the high category (Gueze 2011; MacKinnon 1990; Odum 1971). Community Manggarai people in the mountains of Ruteng utilize 161 plant species in the forest to meet the needs of food, beverage, medicine, timber, controlling pests and toxins, dyes, tools and crafts, fire wood, rope materials, fodder, myths legends and rituals and ornamental plants and fencing. Group of usefulness that have the highest number of plant species are as many as 73 species of medicinal plants (28.57\%) and food as many as 40 species (15.87\%) (Iswandono 2015). Diversity of food and medicine proves that food and health is a key priority of independence of a kampong near the forest conservation (Zuhud et al. 2007). The number of crops that are cultivated Manggarai people in Ruteng Mountains are as many as 45 species (Wawo 1998), whereas those taken directly from the forest as much as 40 species (Iswandono 2015). The use of plants is part of wisdom to survive by exploiting the diversity of species in the forest beside the cultivation of a limited number of species. Species diversity meets the needs of the number and quality of needs (Zhang et al.2013).

\section{Conclusion}

Manggarai community has practiced conservation based on beliefs, values, norms, and tradition inherited. Conservation of cultural impact on forest sustainability is practiced by local people when they act as subjects, not objects, in the management and benefits that sustains their survival. If the local community only serves as an object it will exploit forest products commercially and sustainably that leads to forest degradation. In the remote areas, local culture such as the Manggarai culture related to conservation could be integrated into the activities of the protection, preservation and sustainable use of natural resources. It ensures the sustainable conservation of forests in the long run 
as there are still many rural communities living within or at the fringe of forests in rural Indonesia.

\section{Recommendation}

The Government should implement sustainable forest management by involving local communities as subjects who participated actively in managing the forest. Active involvement of local community based on existing local conservation values, norms and tradition in forest management ensures sustainability of forest resources in the long run. Such a shift in forest management paradigm requires a bold change in national forest policy for effective implementation at local level.

\section{References}

Bohensky EL, Maru Y. 2011. Indigenous knowledge, science, and resilience: what have we learned from a decade of international literature on "integration"? Ecology and Society 16(4):1-6. http://dx.doi.org/10. 5751/ES-04342-160406.

Chennells R. 2013. Traditional knowledge and benefit sharing after the nagoya protocol: three cases from South Africa. Law, Enviromental and Development Journal 9(2):165-183.

Cristancho S, Vining J. 2004. Culturally defined keystone species. Human Ecology Review 11(2):153-164.

Fraser DJ, Coon T, Prince MR, Dion R, Bernatchez L. 2006. Integrating traditional and evolutionary knowledge in biodiversity conservation: a population level case study. Ecology and Society 11(2):1-20.

Freitas DMD, Tagliani PRA. 2009. The use of GIS for the integration of traditional and scientific knowledge in supporting artisanal fisheries management in Southern Brazil. Journal of Enviromental Management 90(6):2071-2080. http://dx.doi.org/10.1016/j.jenvman. 2007.08.026.

Gagnon CA, Berteaux D. 2009. Integrating traditional ecological knowledge and ecological science: a question of scale. Ecology and Society 14(2):1-23.

Garibaldi A, Turner N. 2004. Culturally keystone species: implications for ecological conservation and restoration. Ecology and Society 9(3):1-18.

Gueze M. 2011. Evaluation of tree diversity and utilization: the role of acculturation, a case study in the Bolivian Amazon [dissertation]. Barcelona: Universitat Autonoma de Barcelona.

Hadiwiyono H. 1985. Religi Suku Murba di Indonesia. Jakarta: BPK Gunung Mulia.

Iswandono E. 2015. Pengetahuan etnobotani suku Manggarai dan implikasinya terhadap pemanfaatan tumbuhan hutan di Pegunungan Ruteng. Jurnal Ilmu
Pertanian Indonesia. 20(3):91-101.

Junior P, Sato M. 2005. Ethnoecology and conservation in protected natural areas: incorporating local knowledge in superagui national park management. Brazil Jurnal Biology 65(1):117-127. http://dx.doi.org/10.1590/ S1519-69842005000100016.

Khan ML, Khumbongmayum AD, Tripathi RS. 2008. The sacred groves and their significance in conserving biodiversity an overview. International Journal of Ecology and Environmental Sciences 34(3):277-291.

Koentjaraningrat. 2002. Pengantar Ilmu Antropologi. Jakarta: Rineka Cipta.

Kosmaryandi N. 2012a. Pengembangan Zonasi Taman Nasional: Sintesis Kepentingan Konservasi Keanekaragaman Hayati dan Kehidupan Masyarakat Adat [dissertation]. Bogor: Institut Pertanian Bogor.

Kosmaryandi N. 2012b. New idea for national park zoning system: a synthesis between biodiversity conservation and customary community's tradition. Jurnal Manajemen Hutan Tropika 18(2):69-77. http://dx.doi.org/10.7226/jtfm.18.2.69.

Lawang RMZ. 1999. Konflik Tanah Manggarai-Flores Barat. Jakarta: Universitas Indonesia Press.

MacKinnon J, MacKinnon K, Child G, Thorsell J. 1990. Pengelolaan Kawasan yang Dilindungi di Daerah Tropika. Yogyakarta: Gadjah Mada University Press.

Moller H, Berkes F, Lyyer PO, Kislalioglu M. 2004. Combining science and traditional ecological knowledge: monitoring populations for co-management. Ecology and Society 9(3):1-15.

Naidoo R, Hill K. 2006. Emergence of indigenous vegetation classifications through integration of traditional ecological knowledge and remote sensing analyses. Enviromental Management 38(3):377-387. http://dx.doi.org/10.1007/s00267-004-0338-9.

Nugraha A, Murtijo. 2005. Antropologi Kehutanan. Tangerang: Wana Aksara.

Odum EP. 1971. Fundamentals of Ecology. London: W.B. Saunders Company.

Pei SJ, Zhang G, Huai H. 2009. Application of traditional knowledge in forest management: ethnobotanical indicator of sustainable forest use. Forest Ecology and Management 257:2017-2027. http://dx.doi.org/10. 1016/j.foreco.2009.01.003.

Pei SJ. 2013. Ethnobotany and sustainable use of biodiversity. Plant and Diversity Resources 35(4):401-406.

Rist L, Shaanker R. U, Gulland EJM, Ghazoul J. 2010. The 
use of traditional ecological knowledge in forest management: an example from India. Ecology and Society 15(1):1-20.

Ruheza S, Kilugwe Z. 2012. Integration of the indigenous and the scientific knowledge systems for conservation of biodiversity: significances of their different worldviews and their win-loss relationship. Journal of Sustainable Development in Africa 14(6):160-174.

Simbolon H. 1998. Structure and Species Composition of the Forest in Ruteng Nature Recreation Park, Flores Island. Bogor: LIPI.

Sinu I, Leki S, Klau F, Nur M, Wiendiyanti, Sau P. 1999. Pengkajian Dampak Sosial Ekonomi dan Budaya sebagai Pendukung Pengelolaan Taman Wisata Alam Ruteng, Nusa Tenggara Timur. Ruteng: Universitas Nusa Cendana-Proyek Pengembangan Konservasi Alam Terpadu.

Sinabutar P, Nugroho B, Kartodihardjo, Darusman D. 2014. Reforming the gazettment of state forest area in Riau Province. Jurnal Manajemen Hutan Tropika 20(3):179-186. http://dx.doi.org/10.7226/jtfm.20.3.179.

Sugiyono 2010. Metode Penelitian Administrasi. Bandung: CV Alfabeta.

Sundar A. 2012. Thinking beyond secularism: the catholic church and political practice in rural South India. South Asia Multidisciplinary Academic Journal 2012(1):1-18.

Tongkul F, Lasimbang C, Lasimbang A, Chin P Jr. 2013. Traditional knowledge and sustainable forest management. Unasylva 64(1):41-49.

Trainor C, Lesmana D. 2000. Gunung Berapi, burungburung khas, tikus raksasa dan tenun ikat yang menawan. Bogor: BirdLife International Indonesia Programme.

Turner NJ. 1988. The importance of a rose: Evaluating the cultural significance of plants in Thompson and Lillioet interior salish. American Anthropologist 90(2):272-290. http://dx.doi.org/10.1525/aa.1988.90.2.02a00020.

Uprety Y, Asselin H, Bergeron Y. 2013. Cultural importance of white pine (Pinus strobus L.) to the kitcisakik algonquin community of Western Quebec, Canada. Canadian Journal Forestry Research 43(1):544-551.

Verheijen JAJ. 1991. Manggarai dan Wujud Tertinggi. Jakarta: Lembaga Ilmu Pengetahuan Indonesia.

Wawo AH. 1998. An Ethnobotanical Study of People Around Ruteng Nature Recreation Park, Flores Island. Bogor: LIPI.

Widodo W. 1998. Birds of Flores Island. Bogor: Lembaga Ilmu Pengetahuan Indonesia.

Young JC, Waylen KA, Sarkki S, Albon S, Bainbridge I, Balian E, Davidson J, Edwards D, Fairley R, Margerison C, McCracken D, Owen R, Quine CP, Stewart-Roper C, Thompson D, Tinch R, Van den Hove S, Watt A. 2014. Improving the science-policy dialogue to meet the challenges of biodiversity conservation: having conversations rather than talking at one-another. Biodiversity Conservation 23 (2014):387-404. http://dx.doi.org/10.1007/s10531-013-0607-0.

Zhang LL, Zhang Y, Wang L, Wang YH. 2013. An ethnobotanical study of tradisional edible plants used by naxi people in Nortwest Yunnan, China. Plant and Diversity Resources 35(4):479-486.

Zuhud EAM, Sofyan K, Prasetyo LB, Kartodihardjo H. 2007. Community's attitudes and conservation: an analysis of of kedawung (Parkia timoriana (DC.) Merr.), stimulus of medicinal plant for the community, case in Meru Betiri National Park. Media Konservasi 12(1):22-32. 